\title{
Outpatients' Satisfaction with Received Health Services at Saied Urban Health Center, Tanta, Egypt
}

\author{
Ehab A. Abo Ali ${ }^{1}$ and Walaa M. Shehata ${ }^{1}$.
}

${ }^{1}$ Department of Public Health and Community Medicine, Faculty of Medicine, Tanta University

\begin{abstract}
:
Background: Primary health care (PHC) patient' satisfaction represents a key marker for the quality of health care delivery as it prompts compliance with medical advice and treatment, service utilization, and enhancement of the doctor-patient relationship. Objectives: To assess outpatients' satisfaction with received health services at Saied urban health center, Tanta, Egypt.

Methods: A cross-sectional study included 410 of the outpatients at Saied health center, Tanta, Egypt. Data about sociodemographic factors (gender, age, and marital status, income, employment status, education level, type of residence, and purpose of visit to clinic) were collected from each participant. Patient satisfaction with healthcare service, was assessed by the Short-Form Patient Satisfaction Questionnaire (PSQ-18), comprised of eighteen items which measures total satisfaction and its seven dimensions; general satisfaction, technical quality, interpersonal manner, communication, financial aspects, time spent with doctor and accessibility and convenience.

Results: Total satisfaction rate was 55.9\%. Satisfaction was higher in the dimension of interpersonal manner (78.5\%) and financial aspects (78.5\%). It was lower in the dimension of accessibility and convenience $(33.4 \%)$ and technical quality $(51.2 \%)$. Best satisfactory clinics were ENT $(63.6 \%)$ and family planning $(59.4 \%)$ while the least ones were surgery $(45.5 \%)$ and dermatology $(50.0 \%)$. Older ages and females were more satisfied $(\mathrm{p}<0.05)$.

Conclusion: Patients' total satisfaction was below the accepted, higher in the dimensions of interpersonal manner and financial aspects, but lower in the dimensions of accessibility and convenience and technical quality.
\end{abstract}

Keywords: Egypt, Health center, Outpatients, Satisfaction.

\section{Introduction:}

Health service quality has three dimensions; client quality, professional quality and management quality. Client quality receives most attention in discussions of quality of health care based on how satisfied clients are with their care. ${ }^{1}$ Patient satisfaction is defined as a subjective evaluation of the health service received against client's expectations. ${ }^{2}$

It is principally based on evaluating seven health service dimensions: general countries. $^{4,5}$ The PHC patients' satisfaction represents a key indicator for the quality of health care delivery as it prompts compliance satisfaction, technical quality, interpersonal aspects, communication, financial aspects, time spent with doctor, and the ease of contact or availability. ${ }^{3}$

Patient's satisfaction regarding health care has often been considered as an objective of the health care. It has also been considered as one of the most important measures used for evaluating the health care in general and primary health care (PHC) in particular especially in western with medical advice and treatment, service utilization, and enhancement of the doctorpatient relationship. ${ }^{6,7}$ 
Patient's satisfaction is considered as an internationally accepted factor needed to be studied repeatedly for smooth functioning of the health care systems. ${ }^{7}$ Despite this, the concept and the methodology of assessing patient satisfaction are still underdeveloped in most developing countries. ${ }^{4}$ Satisfaction surveys aim to identify the ways and terms in which patients perceive health services. ${ }^{8,9}$ These studies allow community voices to be heard and affirm the importance of their experiences for the sake of health care planning. ${ }^{9,10}$

In Egypt, the health care infrastructure is reasonable in terms of facilities and personnel but the real challenges are to improve staff performance and patients' satisfaction in attempt to minimize rework, wastage, delay and costs. ${ }^{1}$ The current study aimed to study outpatients' satisfaction with received medical services at Saied Health Center, Tanta, Egypt.

\section{Methods:}

Study design: It is a cross-sectional comparative study.

Study setting, and Participants: The study was conducted during June 2018 at the outpatients' health care of Saied Health Center, Tanta, Egypt. Trained medical students with the assistance of the clinic nurses approached and interviewed patients aged 20 years and older, just after completing clinical consultations and treatment acquirements. Study participants were recruited using systematic random sampling technique. The total sample size was calculated to be 384 based on $50 \%$ expected prevalence rate of health service satisfaction and 0.05 level of accuracy. Study sample was enlarged to 410 patients for better accuracy and reliability. Objectives and benefits of the study were explained to the participants. Patients with acute illnesses and those refusing participation were excluded from the study.

Study tool: A questionnaire consisting of two parts was used in this study. The first part included items on sociodemographic factors (gender, age, and marital status, income, employment status, education level, type of residence, and purpose of visit to clinic). To explore patient satisfaction towards healthcare service, we used the Short-Form Patient Satisfaction Questionnaire (PSQ-18), originally developed by Marshall and Hays1994 (11), and was validated among Egyptians. This self-reported tool could assess health service satisfaction in various clinical settings, including primary healthcare clinics and hospital based outpatient departments. PSQ-18 is composed of eighteen items with 
seven dimensions which measures general satisfaction (2 items), technical quality (4 items), interpersonal manner (2 items), communication (2 items), financial aspects (2 items), time spent with doctor (2 items), and accessibility and convenience (4 items). These items were scored on a five-point Likert scale ranging from 1 (strongly agree) to 5 (strongly disagree). Each dimension that aimed to explore tangible priorities and patient experience on health service satisfaction is evaluated through different related questions that identify a particular area of satisfaction.

Some PSQ-18 items were worded so that agreement reflects satisfaction with medical care, whereas other items were worded so that agreement reflects dissatisfaction with medical care. The scores of items worded to reflect disagreement with medical care were reversed to tabulate the total satisfaction score.

A higher score reflected more satisfaction with medical care. After total items scoring, items within the same subscale were averaged together to create each of the seven subscales scores.

Ethical considerations: Ethical approval of Tanta Faculty of Medicine was obtained prior conduction of the study. Objectives and benefits of the study were explained in verbal and written forms were attached to all questionnaires. A written informed consent for each participant was obtained prior recruitment in the study.

Confidentiality of collected data was assured to all participants. Upon completion of the questionnaire, patients were instructed to put their folded responding sheets into a specified collection pox. Informed oral consents were obtained from those agreed to participate prior proceeding in the study.

Statistical Analysis: Analysis was performed using Statistical Package for Social Sciences (SPSS) (version 16.0, IBM, Armonk, NY). Descriptive presentation for all variables of the study was performed. The Chi squared test was used to test association between qualitative variables. Level of significance was adopted at $\mathrm{p}<0.05$.

\section{Results:}

Out of 410 study participants, $84.1 \%$ aged less than 50. Females constituted the majority $(81.7 \%)$ of the study group. High education was reported by $43.9 \%$ of the participants. Nearly half of study participants (48.5\%) were housewives and nearly two thirds of them (63.7\%) were urban residents. The majority of participants $(89.5 \%)$ were married, and most of them (66.3\%) reported having just enough 
income (Table-1). Total satisfaction rate was $55.9 \%$. Indifference and dissatisfaction rates were 25.6 and $18.5 \%$, respectively.

Satisfaction was the highest in the dimensions of "interpersonal manner" (78.5\%) and "financial aspects" (78.5\%), while it was the lowest in the dimensions of "accessibility and convenience" (33.4\%) and "technical quality"(51.2\%).The highest dissatisfactory dimensions were "accessibility and convenience" followed by "time spent with doctors" (43.2 and 28.8\%, respectively) (Table-2).

Older ages ( $\geq 30$ year) were found to be more satisfied comparable with those less than 30 year. The difference was statistically significant $(\mathrm{P}<0.05)$. Also, females and housewives were more significantly satisfied than males and other occupations, respectively $(\mathrm{P}<0.05)$. On the other hand, no association between level of satisfaction and educational level, residence, marital status and family income was found $(\mathrm{P}>0.05)($ Table-3).

Best satisfactory clinics were ENT (63.6\%) and family planning (59.4\%) while the least ones were surgery (45.5\%) and dermatology $(50.0 \%)$. The most unsatisfactory clinic was surgery $(27.3 \%)$ while the least unsatisfactory one was dermatology (11.1\%).
Patients attending the clinic as new cases were comparable to those attending for follow-up visits $(\mathrm{P}>0.05)($ Table 4$)$.

\section{Discussion:}

The satisfied patient is more likely to develop a stronger and long lasting relationship with their medical providers, leading to improved compliance, continuity of care, and eventually better health outcomes. ${ }^{12}$ The current study aimed to explore the outpatient's satisfaction as well as, its associated factors regarding medical care in a primary health care center in an Egyptian city. It was found that, just above the half of our study participants were satisfied with PHC outpatient services.

This was near to Al-Sakkak et al., $2008^{13}$ findings in Saudi Arabia which showed that only $64.2 \%$ of their patients were satisfied. In another study done by Metwally, 2014 ${ }^{12}$ in two different Egyptian cities, she found that patients in Alexandria (68\%) are more satisfied with PHC services than patients in Sohag (46\%). Also, Al-azmi et al. $2006^{14}$ in Kuwait found that nearly one fifth of the participants (19\%) were highly satisfied, $43 \%$ were satisfied with the service and $38 \%$ were dissatisfied.

Regarding the satisfaction dimensions, it was surprising that the level of patients' satisfaction was the highest in both 
interpersonal manner and financial aspects subscales in spite of the daily overloading of care providers with large numbers of patients and the limited resources in a developing country like Egypt. The least level of satisfaction was in the dimension of accessibility and convenience.

This was inconsistent with Ganasegeran et al. 2015 findings in their study in Malaysia $^{15}$ as they declared that patients' satisfaction was the highest in terms of technical quality followed by accessibility and convenience and the lowest was in time spent with doctors. While Alshammari, 2014 revealed that interpersonal manner was the highest scoring dimension followed by the technical quality then communication and the lowest scoring dimensions were accessibility and availability. ${ }^{16}$

The relationships between the patients' sociodemographic characteristics and their satisfaction about the received health care may help health care providers to meet the different needs of patients based on their age, sex and socio-economic status as addressed by Mercer et al., 2008; Lin et al., 2010 and Abutiheen, 2014. ${ }^{17-19}$

In the current study, It was found that; an association between the age of the patients and their level of satisfaction. It was noticed that the older age groups reported that they were more satisfied comparable to the younger ones. The same finding was observed by another study in Riyadh by Al-Sakkak et al., $2008^{13}$ and Alshammari $2014^{16}$ in Hail city, Saudi Arabia. This may be attributed to the lower expectations of service quality among older patients.

Females showed higher level of satisfaction comparable to males. This finding was consistent with Almoajel et al.,2014 ${ }^{5}$ findings in Jubail City, Saudi Arabia who found that females showed the highest satisfaction level $(94.3 \%)$ but in contrast with Al-Dawood and Elzubier ${ }^{20}$ study which showed that males were more satisfied. The current study revealed that patients with lower levels of education had higher levels of satisfaction which is consistent with the findings of Al-Sakkak MA et al., 2008. ${ }^{13}$

This may be attributed to a potentially greater service expectation by the more highly educated patients.

In the present study, it was found that; there was a significant relationship between the level of satisfaction and occupation which is similar to Almoajel et al., $2014^{5}$ findings. However, there was no significant association between patients' residence and their satisfaction. On the other side, Ganasegeran et 
al., $2015^{15}$ found a significant difference in their study in Malaysia. This may be attributed to differences in the distribution and accessibility of the health services in urban and rural areas in both countries.

In the current study, there was no significant association between the level of patients' satisfaction and the purpose of the visit to the outpatient clinic. On the other side, Ganasegeran et al. 2015 found a significant association. ${ }^{15}$ Both studies revealed that new cases were more satisfied with the received medical services than follow up ones.

\section{Study limitations:}

The present study described the patients' satisfaction with provided medical services at an urban health center, which does not necessarily represent all the sectors of primary health care.

\section{Conclusion:}

Total satisfaction rate was below the accepted level. Satisfaction was higher in the dimensions of interpersonal manner and financial aspects, while it was lower in the dimensions of accessibility and convenience and technical quality. Older ages and females were more satisfied. Periodic professional development and training programs for doctors, as well as technical development of the clinics, are required for a better performance.

Conflict of interests: The authors declare that they have no competing interests

Funding: The authors declare that they did not receive any funds in design of the study and collection, analysis, and interpretation of data and in writing the manuscript.

\section{References:}

1. Gadallah M, Zaki B, Rady M et al. Patient satisfaction with primary health care services in two districts in Lower and Upper Egypt. East Mediterr Health J. 2003; 9(3):422-430.

2. Nabbuye-Sekandi J, Makumbi F, Kasangaki A et al. Patient satisfaction with services in outpatient clinics at Mulago hospital, Uganda. International Journal for Quality in Health Care. 2011; 23(5): 516-523.

3. World Health Organization. A framework for measuring responsiveness," GPE Discussion.Paper Series 32, WHO, Geneva, Switzerland, 2008.

4. Harutyunyan T, Demirchyant A, Thompson M. Patient satisfaction with primary care in Armenia: good rating of 
bad services? Health Serv Manage Res. 2010; 23(1):12-17.

5. Almoajel A, Fetohi E, Alshamrani A. Patient Satisfaction with Primary Health Care in Jubail City, Saudi Arabia.World Journal of Medical Sciences. 2014; 11(2):225-264

6. Ganasegeran K, Al-Dubai S. Medical professionalism from a socio-cultural perspective: evaluating medical residents' communicative attitudes during the medical encounter in Malaysia. Journal of Postgraduate Medicine. 2014; 60(1): 12-15.

7. Mohamed E, Sami W, Alotaibi A et al. Patients' Satisfaction with Primary Health Care Centers' Services, Majmaah, Kingdom of Saudi of Saudi Arabia.Int J Health Sci .2015;9(2):163-170.

8. Williams B. Patient satisfaction: A valid concept? SocSci Med.1994; 38:509-516.

9. Bodour S, Zdemur YE and Kara F. Outpatient Satisfaction with Health Centers in Urban Areas. Turk J Med Sci. 2002; 32:409-414.

10. Gilson L, Alilio M, Heggenhougen K. Community satisfaction with primary health care services: An evaluation undertaken in the Morogoro region of
Tanzania. SocSci Med. 1994; 39:767780.

11. Marshall G, Hays R. The Patient Satisfaction Questionnaire Short Form (PSQ-18). Santa Monica, CA: RAND Corporation.1994; p. 7865.

12. Metwally D. Patients' Satisfaction with Primary Health Care in Egypt: Exploring the Gap between Rural and Urban Governorates. Journal of Social and Development Sciences. 2014; 5(4): 221230.

13. Al-Sakkak M, Al-Nowaiser N, AlKhashan H.et al. Patient satisfaction with primary health care services in Riyadh. Saudi Med J. 2008; 29(3):432-436.

14. Al-Azmi S, Mohammed A, Hanafi M. Patients' Satisfaction with primary health care in Kuwait after electronic medical record implementation. J Egypt Public Health Assoc. 2006; 81 (5 \& 6): 278-300.

15. Ganasegeran K, Perianayagam W, Rizal Abdul Manaf R et al. Patient Satisfaction in Malaysia's Busiest Outpatient Medical Care. The Scientific World Journal. 2015;2015:1- 6 .

16. Alshammari F. Patient satisfaction in primary health care centersin Hail city, Saudi Arabia. American Journal of 
Applied Sciences. 2014; 11 (8): 12341240.

17. Mercer L, Tanabe $\mathrm{P}$, Pang $\mathrm{M}$ et al. Patient perspectives on communication with the medical team: Pilot study using the communication assessment tool-team (CAT-T). Patient Edu Counseling. 2008; 73: 220-223.

18. Lin B, Lin C, Line Y. Patient satisfaction evaluations in different clinic caremodels: Care stratification under a national demonstration project. Health Place. 2010; 16: 85-92.
19. Abutiheen A. Clients satisfaction with referral system in Karbala. AmJ Applied Sci.2014; 11: 216-222.

20. Al-Dawood K, Elzubier A.Patients' expectations and satisfaction in a teaching hospital outpatient clinic, Al Khobar, Saudi Arabia.Saudi medical journal.1996; 17(2):245-250. 
Table (1): Socio-demographic characteristics of study participants

\begin{tabular}{|c|c|c|}
\hline \multirow{2}{*}{ Socio-demographic characteristics } & \multicolumn{2}{|c|}{$\begin{array}{c}\text { Study participants } \\
(\mathrm{n}=410)\end{array}$} \\
\hline & No. & $\%$ \\
\hline \multicolumn{3}{|l|}{ Age(years): } \\
\hline - $<30$ & 172 & 41.9 \\
\hline - $30-$ & 173 & 42.2 \\
\hline - $\geq 50$ & 65 & 15.9 \\
\hline \multicolumn{3}{|l|}{ Gender: } \\
\hline - Male & 75 & 18.3 \\
\hline - Female & 335 & 81.7 \\
\hline \multicolumn{3}{|l|}{ Education: } \\
\hline - Basic education & 92 & 22.4 \\
\hline - Secondary school & 138 & 33.7 \\
\hline - High education & 180 & 43.9 \\
\hline \multicolumn{3}{|l|}{ Occupation: } \\
\hline - Unemployed & 74 & 18.0 \\
\hline - House wife & 199 & 48.5 \\
\hline - Unskilled worker & 21 & 5.1 \\
\hline - Skilled worker & 58 & 14.1 \\
\hline - Professional & 58 & 14.1 \\
\hline \multicolumn{3}{|l|}{ Residence: } \\
\hline - Urban & 261 & 63.7 \\
\hline - Rural & 149 & 36.3 \\
\hline \multicolumn{3}{|l|}{ Marital status: } \\
\hline - Married & 367 & 89.5 \\
\hline - Unmarried & 43 & 10.5 \\
\hline \multicolumn{3}{|l|}{ Family income: } \\
\hline - Not enough & 102 & 24.9 \\
\hline - Just enough & 272 & 66.3 \\
\hline - Enough and saving & 36 & 8.8 \\
\hline
\end{tabular}


61

Table (2): Total satisfaction and satisfaction dimensions subscales among study participants $(\mathbf{n}=\mathbf{4 1 0})$

\begin{tabular}{|c|c|c|c|c|c|c|}
\hline \multirow{3}{*}{$\begin{array}{c}\text { Total satisfaction } \\
\text { and } \\
\text { Satisfaction dimensions subscales }\end{array}$} & \multicolumn{6}{|c|}{$\begin{array}{l}\text { Study participants } \\
\qquad(\mathrm{n}=\mathbf{4 1 0})\end{array}$} \\
\hline & \multicolumn{2}{|c|}{$\begin{array}{c}\text { Dissatisfied } \\
\quad(n=76)\end{array}$} & \multicolumn{2}{|c|}{$\begin{array}{c}\text { Indifferent } \\
(n=105)\end{array}$} & \multicolumn{2}{|c|}{$\begin{array}{c}\text { Satisfied } \\
(\mathrm{n}=229)\end{array}$} \\
\hline & No. & $\%$ & No. & $\%$ & No. & $\%$ \\
\hline - Total satisfaction & 76 & 18.5 & 105 & 25.6 & 229 & 55.9 \\
\hline - General satisfaction & 84 & 20.5 & 71 & 17.3 & 255 & 62.2 \\
\hline - Technical quality & 107 & 26.1 & 93 & 22.7 & 210 & 51.2 \\
\hline - Interpersonal manner & 40 & 9.8 & 48 & 11.7 & 322 & 78.5 \\
\hline - Communication & 93 & 22.7 & 65 & 15.8 & 252 & 61.5 \\
\hline - Financial aspects & 30 & 7.3 & 58 & 14.2 & 322 & 78.5 \\
\hline - Time spent with doctors & 118 & 28.8 & 50 & 12.2 & 242 & 59.0 \\
\hline - Accessibility and convenience & 177 & 43.2 & 96 & 23.4 & 137 & 33.4 \\
\hline
\end{tabular}


Table (3): Total satisfaction in relation to socio-demographic characteristics among study participants $(n=410)$

\begin{tabular}{|c|c|c|c|c|c|c|c|c|}
\hline \multirow{3}{*}{$\begin{array}{l}\text { Socio-demographic } \\
\text { characteristics }\end{array}$} & \multicolumn{6}{|c|}{ Satisfaction } & \multirow{3}{*}{$\chi^{2}$} & \multirow{3}{*}{$P$ value } \\
\hline & \multicolumn{2}{|c|}{$\begin{array}{c}\text { Dissatisfied } \\
(n=76)\end{array}$} & \multicolumn{2}{|c|}{$\begin{array}{l}\text { Indifferent } \\
(n=105)\end{array}$} & \multicolumn{2}{|c|}{$\begin{array}{c}\text { Satisfied } \\
(\mathrm{n}=229)\end{array}$} & & \\
\hline & No. & $\%$ & No. & $\%$ & No. & $\%$ & & \\
\hline $\begin{aligned} \text { Age(years): } \\
\cdot \quad<30 \\
\cdot \quad 30- \\
\cdot \quad \geq 50\end{aligned}$ & $\begin{array}{l}41 \\
23 \\
12\end{array}$ & $\begin{array}{l}53.9 \\
30.3 \\
15.8\end{array}$ & $\begin{array}{l}49 \\
43 \\
13\end{array}$ & $\begin{array}{l}46.7 \\
40.9 \\
12.4\end{array}$ & $\begin{array}{c}82 \\
107 \\
40\end{array}$ & $\begin{array}{l}35.8 \\
46.7 \\
17.5\end{array}$ & 10.115 & $0.039 *$ \\
\hline $\begin{aligned} & \text { Gender: } \\
& \text { - } \text { Male } \\
& \text { - } \text { female }\end{aligned}$ & $\begin{array}{l}26 \\
50\end{array}$ & $\begin{array}{l}34.2 \\
65.8\end{array}$ & $\begin{array}{l}18 \\
87\end{array}$ & $\begin{array}{l}17.1 \\
82.9\end{array}$ & $\begin{array}{c}31 \\
198\end{array}$ & $\begin{array}{l}13.5 \\
86.5\end{array}$ & 16.442 & $0.000^{*}$ \\
\hline $\begin{array}{ll}\text { Education: } \\
\text { - } \text { Basic education } \\
\text { - Secondary school } \\
\text { - } \text { High education }\end{array}$ & $\begin{array}{l}15 \\
28 \\
33\end{array}$ & $\begin{array}{l}19.7 \\
36.8 \\
43.5\end{array}$ & $\begin{array}{l}21 \\
34 \\
50\end{array}$ & $\begin{array}{l}20.0 \\
32.4 \\
47.6\end{array}$ & $\begin{array}{l}56 \\
76 \\
97\end{array}$ & $\begin{array}{l}24.5 \\
33.2 \\
42.3\end{array}$ & 1.694 & 0.792 \\
\hline $\begin{array}{c}\text { Occupation: } \\
\text { - Unemployed } \\
\text { - House wife } \\
\text { - Unskilled worker } \\
\text { - } \text { Skilled worker } \\
\text { - Professional }\end{array}$ & $\begin{array}{c}12 \\
23 \\
6 \\
21 \\
14\end{array}$ & $\begin{array}{c}15.8 \\
30.3 \\
7.9 \\
27.6 \\
18.4\end{array}$ & $\begin{array}{c}24 \\
52 \\
4 \\
16 \\
9\end{array}$ & $\begin{array}{c}22.9 \\
49.5 \\
3.8 \\
15.2 \\
8.6\end{array}$ & $\begin{array}{c}38 \\
124 \\
11 \\
21 \\
35\end{array}$ & $\begin{array}{c}16.6 \\
54.1 \\
4.8 \\
9.2 \\
15.3\end{array}$ & 27.468 & $0.001^{*}$ \\
\hline \begin{tabular}{cc}
\multicolumn{2}{l}{ Residence: } \\
- $\quad$ Urban \\
- $\quad$ Rural
\end{tabular} & $\begin{array}{l}52 \\
24\end{array}$ & $\begin{array}{l}68.4 \\
31.6\end{array}$ & $\begin{array}{l}70 \\
35\end{array}$ & $\begin{array}{l}66.7 \\
33.3\end{array}$ & $\begin{array}{c}139 \\
90\end{array}$ & $\begin{array}{l}60.7 \\
39.3\end{array}$ & 2.023 & 0.364 \\
\hline $\begin{array}{c}\text { Marital status: } \\
\text { - } \quad \text { Married } \\
\text { - } \quad \text { Unmarried }\end{array}$ & $\begin{array}{c}67 \\
9\end{array}$ & $\begin{array}{l}88.2 \\
11.8\end{array}$ & $\begin{array}{l}90 \\
15\end{array}$ & $\begin{array}{l}85.7 \\
14.3\end{array}$ & $\begin{array}{c}210 \\
19\end{array}$ & $\begin{array}{c}91.7 \\
8.3\end{array}$ & 2.933 & 0.231 \\
\hline $\begin{array}{l}\text { Family income: } \\
\text { - Not enough } \\
\text { - Just enough } \\
\text { - Enough and saving }\end{array}$ & $\begin{array}{c}21 \\
49 \\
6\end{array}$ & $\begin{array}{c}27.6 \\
64.5 \\
7.9\end{array}$ & $\begin{array}{l}23 \\
69 \\
13\end{array}$ & $\begin{array}{l}21.9 \\
65.7 \\
12.4\end{array}$ & $\begin{array}{c}58 \\
154 \\
17\end{array}$ & $\begin{array}{c}25.3 \\
67.2 \\
7.5\end{array}$ & 2.796 & 0.592 \\
\hline
\end{tabular}


63

Table (4): Total satisfaction in relation to specialty of the clinic and purpose of the visit among study participants $(n=410$

\begin{tabular}{|c|c|c|c|c|c|c|c|c|c|}
\hline \multirow{3}{*}{$\begin{array}{l}\text { Specialty of the clinic } \\
\text { and } \\
\text { Purpose of the visit }\end{array}$} & \multicolumn{6}{|c|}{ Satisfaction } & \multirow{3}{*}{ Total } & \multirow{3}{*}{$\begin{array}{c}\text { Test of } \\
\text { significance }\end{array}$} & \multirow{3}{*}{$P$ value } \\
\hline & \multicolumn{2}{|c|}{$\begin{array}{c}\text { Dissatisfied } \\
(n=76)\end{array}$} & \multicolumn{2}{|c|}{$\begin{array}{c}\text { Indifferent } \\
(n=105)\end{array}$} & \multicolumn{2}{|c|}{$\begin{array}{c}\text { Satisfied } \\
(n=229)\end{array}$} & & & \\
\hline & No. & $\%$ & No. & $\%$ & No. & $\%$ & & & \\
\hline \multicolumn{8}{|l|}{ Specialty of clinic: } & \multirow{10}{*}{$\begin{array}{c}\text { Monte Carlo } \\
\text { Exact Test }\end{array}$} & \multirow{10}{*}{.427} \\
\hline - Internal Medicine & 10 & 27.0 & 7 & 18.9 & 20 & 54.1 & 37 & & \\
\hline - $\quad$ Surgery & 3 & 27.3 & 3 & 27.3 & 5 & 45.5 & 11 & & \\
\hline - Pediatric & 13 & 12.6 & 30 & 29.1 & 60 & 58.3 & 103 & & \\
\hline $\begin{array}{l}\text { - Gynecology and } \\
\text { obstetrics }\end{array}$ & 13 & 18.6 & 21 & 30.0 & 36 & 51.4 & 70 & & \\
\hline - ENT & 3 & 27.3 & 1 & 9.1 & 7 & 63.6 & 11 & & \\
\hline - Family Planning & 20 & 19.8 & 21 & 20.8 & 60 & 59.4 & 101 & & \\
\hline - Dental care & 9 & 19.1 & 13 & 27.7 & 25 & 53.2 & 47 & & \\
\hline - Ophthalmology & 3 & 25.0 & 2 & 16.7 & 7 & 58.3 & 12 & & \\
\hline - Dermatology & 2 & 11.1 & 7 & 38.9 & 9 & 50.0 & 18 & & \\
\hline \multicolumn{8}{|l|}{ Purpose of the visit: } & \multirow[t]{3}{*}{$\begin{array}{l}\text { Pearson Chi- } \\
\text { Square }\end{array}$} & \multirow[b]{3}{*}{0.779} \\
\hline - New case & 30 & 17.5 & 42 & 24.6 & 99 & 57.9 & 171 & & \\
\hline - Follow up visit & 46 & 19.2 & 63 & 26.4 & 130 & 54.4 & 239 & & \\
\hline
\end{tabular}




\section{الملخص العربى}

رضاء مرضى العيادات الخارجية عن الخدمات الصحية المتلقاه بمركزسعيد الصحي الحضري ـ طنطاـ مصر

$$
\text { ايهاب عبد الحليم أبو علي- و لاء حمح شحاته }
$$

الخلفية: يمثل رضـا المرضى في مجـال الرعاية الصحية الأولية علامـة رئيسية لجودة تقديم الرعايـة الصحية، حيث إنـه يحث على الالتزام بالمشورة الطبية و العلاج، و استخدام الخدمة، وتعزيز العلاقة بين الطبيب و المريض. الهُف: تقييم رضا مرضى العيادات الخارجيه عن الخدمات الصحية المتلقاة في مركز سعيد الصحي الحضري، طنطا، مصر طرق البحث: شملت الدراسة المستعرضة 410 من مرضى العيادات الخارجية بمركز سعيد الصحي الحضري، طنطا، مصر. تم جمع بيانات عن العو امل الاجتماعية و الديمو غر افية (الجنس،العمر ،و الحالة الاجتماعية،الدخل،حالة التوظيف،مستوى التعليم،نوع الإقامة،و الغرض من زيارة العيادة) من كل مشارك. تم تقييم رضا المرضى عن خدمة الرعاية الصحية، من خلال استبيان رضا المرضى المختارين (PSQ-18) ، ويتكون

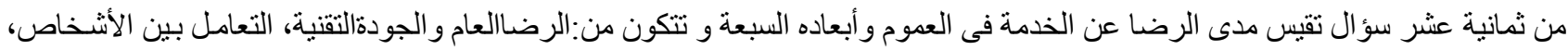
التو اصل، الجو انب المالية، والوقت الذي يقضيه مع الطبيب وسهولة الوصول إليهاو الراحة. النتائج: كان معدل الرضا الإجمالي 55.9 ٪. كانت نسبةالرضا أعلى في التعامل بين الأشخاص و الجو انب الماليـة (78.5\%) ، بينمـا كانت أقل في أبعاد الوصول و الر احة (33.4٪) و الجودة التقنية(21.2\%). وكانت أفضل عيادات مرضيةهي الأنف و الأذن و الحنجرة (63.6٪) وتنظيم

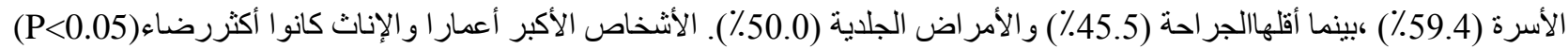
الأستتتاجات: كان معدل الرضـا الإجمالي أقل من المقبول، أعلى في التعامل بين الأشخاص و الجو انب المالية ولكنها كانت أقل في أبعاد الوصول و الر احة و الجودة التقنية. الكلمات الدالة:العيادات الخارجية ، الرضا، المركز الصحي،مصر الصر 